\title{
Wheat Bread with Pumpkin (Cucurbita maxima L.) Pulp as a Functional Food Product
}

\author{
Renata Różyło ${ }^{1 *}$, Urszula Gawlik-Dziki², Dariusz Dziki³, Anna Jakubczyk², \\ Monika Karaśs and Krzysztof Różyło
}

${ }^{1}$ Department of Equipment Operation and Maintenance in the Food Industry, University of Life Sciences in Lublin, Doświadczalna Str. 44, PL-20-280 Lublin, Poland

${ }^{2}$ Department of Biochemistry and Food Chemistry, University of Life Sciences in Lublin, Skromna Str. 8, PL-20-704 Lublin, Poland

${ }^{3}$ Thermal Engineering Department, University of Life Sciences in Lublin, Doświadczalna Str. 44, PL-20-280 Lublin, Poland

${ }^{4}$ Department of Agricultural Ecology, Faculty of Agrobioengineering, University of Life Sciences in Lublin, Akademicka Str. 13, PL-20-950 Lublin, Poland

Received: December 10, 2013 Accepted: July 16, 2014

\begin{abstract}
Summary
In this study, a new application of pumpkin pulp in bread production is shown. The aim of this work is to determine the influence of the addition of fresh pumpkin pulp directly into wheat flour on physical, sensorial and biological properties of bread. The bioaccessibility of active compounds was also studied. An increase in the addition of pumpkin pulp from 5 to $20 \%$ (converted to dry matter) caused a decrease of bread volume and increase of crumb hardness and cohesiveness. The sensory characteristics of the bread showed that a partial replacement of wheat flour with up to $10 \%$ of pumpkin pulp gave satisfactory results. The taste, aroma and overall acceptability of control bread and bread containing 5 or $10 \%$ of pulp had the highest degree of liking. The addition of higher levels of pumpkin pulp caused an unpleasant aroma and taste. Pumpkin pulp is a good material to complement the bread with potentially bioaccessible phenolics (including flavonoids) and, especially, with peptides. The highest antioxidant activity was observed, in most cases, of the samples with added 10 and $15 \%$ of pumpkin pulp. The addition of the pulp significantly enriched the bread with potentially bioaccessible angiotensin-converting enzyme (ACE) inhibitors. The highest activity was determined in the bread with 15 and $20 \%$ pumpkin pulp. ACE inhibitors from the tested bread were highly bioaccessible in vitro. Pumpkin pulp seems to be a valuable source of active compounds to complement the wheat bread. Adding the pulp directly to the wheat flour gives satisfactory baking results and reduces the cost of production. Additionally, pumpkin pulp is sometimes treated as waste material after the acquisition of seeds, thus using it as bread supplement also has environmental and economic benefits.
\end{abstract}

Key words: pumpkin, bread, texture, antioxidants, bioaccessibility in vitro, angiotensin-converting enzyme (ACE) inhibition

\section{Introduction}

Epidemiological studies strongly suggest that diet plays a significant role in the prevention of many chronic diseases associated with free radical reactions. Nowadays, hypertension is the most common risk factor for coronary heart disease, stroke and renal disease $(1,2)$. It is

*Corresponding author: Phone: +48 (82) 461 0061; E-mail: renata.rozylo@up.lublin.pl 
associated with excessive activity of angiotensin-converting enzyme (ACE), part of the renin-angiotensin-aldosterone system (RAAS), which plays important roles in the regulation of blood pressure, performing a protective function for the heart and blood circulation system (3). The plant material such as seeds (4), fruits (5) and vegetables (6) are rich in antioxidants and therefore should be a significant part of our diet.

Pumpkin (Cucurbita sp.) is cultivated throughout the world for use as vegetable as well as medicine. Pumpkin itself is a high-yield vegetable, easy to grow, and consequently inexpensive. Pumpkin flesh is a delicious and fully appreciated additive in a diversity of products for children and adults. Pumpkin has received considerable attention in recent years because of the nutritional and health-protective value $(7,8)$. Fruits are a source of valuable vitamins, minerals, fibre, carbohydrates and antioxidants (9). Polysaccharides from pumpkin have hypoglycemic activity and pumpkin-rich diet could reduce blood glucose (10). Pumpkin fruits are consumed in a variety of ways such as fresh or after thermal treatment of vegetables.

There are some works investigating the influence of the addition of pumpkin flesh or seeds on bread properties. However, they are focused on bread supplementation with pumpkin flour obtained after drying and grinding flesh or seeds (11-15). Such preparation of pumpkin flour is expensive. Thus, we decided to add the ground pumpkin pulp directly to the wheat flour.

The aim of this work is to evaluate the influence of pumpkin pulp addition to wheat flour on the properties of bread. The physical properties, sensory characteristics and biological activity of bread in the light of potential bioaccessibility of active compounds are described.

\section{Materials and Methods}

\section{Chemicals}

Ferrozine (3-(2-pyridyl)-5,6-bis-(4-phenyl-sulphonic acid)-1,2,4-triazine), ABTS (2,2'-azino-bis(3-ethylbenzothiazoline-6-sulphonic acid), $\alpha$-amylase (EC 3.2.1.1), pancreatin (from hog pancreas, EC 232-468-9, activity 8×USP (United States Pharmacopeia)), pepsin (EC 3.4.23.1), trypsin (EC 3.4.21.4), bile extract (porcine, EC 232-468-9), linoleic acid, ammonium thiocyanate, haemoglobin and phosphate-buffered saline (PBS; $0.01 \mathrm{M}$ phosphate buffer, $0.0027 \mathrm{M}$ potassium chloride and $0.137 \mathrm{M}$ sodium chloride, $\mathrm{pH}=7.4$, at $25^{\circ} \mathrm{C}$ ) were purchased from Sigma-Aldrich Company (Poznan, Poland). All other chemicals were of analytical grade.

\section{Materials}

Bread flour (white flour type 750) contained the following: protein $11.5 \%$ (16), gluten $26 \%$ (17), ash $0.76 \%$

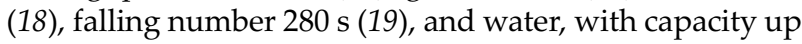
to $500 \mathrm{BU}$ (Brabender Units), 55 \% (20). The wheat bread flour was obtained from the local milling industry, and the dried instant yeast from Instaferm ${ }^{\circledR}$ (Lallemand Iberia, SA, Setúbal, Portugal). Salt and sugar were purchased from the local market. Tap water was used in this study.
Pumpkin fruits (Cucurbita maxima L.) cv. Bambino were harvested from the Experimental Station of the University of Life Sciences in Lublin, Poland. The rind, fibrous matter and seeds were removed and the flesh was cut into small pieces about $2 \mathrm{~cm} \times 2 \mathrm{~cm} \times 2 \mathrm{~cm}$, and was pulped in a knife pulper until a homogeneous mass passed through the 350- $\mu$ m sieve (Model 2001, Braun, Neu-Isenburg, Germany). The obtained pumpkin pulp consisted of (in \% on wet basis): moisture 84.6, fibre 6.1, protein 5.7, carbohydrates 5.4 and fat 1.2 . Fresh pumpkin pulp was added directly to the wheat flour during dough preparation.

\section{Experimental baking}

The experimental baking was a small-scale straightdough baking test according to the Berlin Institute of Technology (21). The dough was prepared with different amounts of homogenized pumpkin pulp based on the percentage of dry matter determined in the range from 0 to $20 \%$ of the total amount of flour (i.e. 32.5, 64.9, 97.4 and $129.9 \mathrm{~g}$ of fresh pumpkin pulp ( $84.6 \%$ moisture) was added per $100 \mathrm{~g}$ of wheat flour to obtain 5, 10, 15 and $20 \%$ of pulp, respectively). The dough was prepared from the following ingredients: flour, water (58 \% on flour basis), salt ( $2 \%$ on flour basis) and dried instant yeasts (in an amount equivalent to $3 \%$ of compressed yeasts). Loaves of bread were prepared after mixing $(8 \mathrm{~min})$ the dough (300-gram pieces) in a slow-speed mixer (type GM-2, Sadkiewicz Instruments, Bydgoszcz, Poland), fermenting ( $30^{\circ} \mathrm{C}, 75-88$ $\%$ relative humidity $(\mathrm{RH}), 60 \mathrm{~min}$, with 1 min transfixion) and proving $\left(30^{\circ} \mathrm{C}\right.$ and $75 \% \mathrm{RH}, 60 \mathrm{~min}$ ) in a fermentation chamber (Sadkiewicz Instruments). The loaves were baked at $230{ }^{\circ} \mathrm{C}$ for $25 \mathrm{~min}$ in a laboratory oven (Sadkiewicz Instruments). Live steam was injected for $1 \mathrm{~min}$ immediately after the loaves were placed in the oven. Baking tests were performed in six replicates. After baking, the bread was cooled for $2 \mathrm{~h}$ at room temperature $\left(21^{\circ} \mathrm{C}\right)$ and then wrapped in polyethylene bags.

\section{Evaluation of physical properties of bread}

The mass and volume of the baked bread were determined (21) and the bread loaf volume per $100 \mathrm{~g}$ of flour was calculated $(21,22)$. The $\mathrm{pH}$ of the bread crumbs was measured using a pH meter (TESTO 206-pH2, Pruszków, Poland) with penetration probe for semi-solid substances (including baked products).

The porosity of bread crumbs was estimated using the Dallmann scale in the range of 30-100 (23). Crumb grain structure was evaluated and compared visually with numbered pattern pictures of crumb structure. The crumbs with the smallest pores and the densest structure had the highest score. Samples characterized by a loose structure with large pores scored the lowest.

Textural profile analysis (TPA) of bread crumbs was performed one day and three days after baking. The measurements were made with the help of the ZWICK Z020/ TN2S (Zwick Roell Group, Ulm, Germany) strength tester. The loaves were sliced mechanically. The slices were cut from the middle part of the loaf $(30 \mathrm{~mm} \times 30 \mathrm{~mm} \times 20$ $\mathrm{mm}$, central region of the bread slice) and the tests were 
done in 12 replicates. In a two-bite test (24), the samples were compressed twice (curves 1 and 2), from which textural parameters were obtained: hardness (peak force 1), elasticity (length of base of area 2), cohesiveness (area 2/ area 1 ), chewiness (firmness $\times$ elasticity $\times$ cohesiveness). For assessing the changes of textural properties caused by storage (degree of staling), the percentage changes of hardness were evaluated. The bread crumb texture heterogeneity (25) was assessed from the hardness variations in the entire profile of the bread slice in four samples (30 $\mathrm{mm} \times 30 \mathrm{~mm} \times 10 \mathrm{~mm}$ ) from the slice, in six replicates.

\section{Sensory evaluation}

Sensory evaluation was carried out on bread samples with different percentages of pumpkin pulp. Subsequently, the samples were sliced mechanically (slices about 1.5 $\mathrm{cm}$ thick), coded with a number and served to untrained consumers. The panel consisted of 52 frequent consumers (22-50 years old, 31 females and 21 males), who evaluated the overall acceptability of the bread. This hedonic test was used to determine the degree of overall liking of different types of bread according to a nine-point hedonic scale (1=dislike extremely, 5=neither like nor dislike, 9=like extremely). Tap water was used for mouth rinsing before and after each sample testing (26-29).

\section{Determination of biological activity of bread \\ Extraction procedure}

Samples of prepared bread (1 g of dry mass, dm) were extracted for $1 \mathrm{~h}$ with $20 \mathrm{~mL}$ of PBS buffer $(\mathrm{pH}=7.4)$ The extracts were separated by decantation and the residues were extracted again with $20 \mathrm{~mL}$ of PBS buffer. Then, the extracts were combined and stored in darkness at $-20^{\circ} \mathrm{C}$. For the estimation of the potential bioaccessibility in vitro, digestion was evaluated according to the procedure described by Gawlik-Dziki et al. (30).

\section{Analytical procedures}

Total phenolic content was estimated according to Singleton and Rossi (31) and expressed as gallic acid equivalent (mg per $\mathrm{g}$ of $\mathrm{dm}$ ). Total flavonoid content was determined according to Bahorun et al. (32) and expressed as quercetin equivalents (mg per $\mathrm{g}$ of $\mathrm{dm}$ ). The concentration of peptides was calculated from the soluble peptide content determined by the trinitrobenzenesulphonic acid method with L-leucine as the standard (33).

For antiradical activity analyses, the improved ABTS decolourisation assay was performed (34). Chelating and ferric reducing antioxidant power (CHEL and FRAP, respectively) were determined according to the methods described by Guo et al. (35) and Oyaizu (36), respectively. FRAP was calculated as $\mathrm{EC}_{50}$ value $(\mathrm{mg} / \mathrm{mL}$; half of the maximum effective concentration at which the absorbance was 0.5 and was obtained by interpolation from linear regression analysis). The $\mathrm{OH}^{\bullet}$ scavenging assay was performed according to the procedure described by $\mathrm{Su}$ et al. (37). Angiotensin-converting enzyme (ACE) was prepared according to the procedure of Hayakari et al. (38). The ACE inhibitory activity (ACEI) was measured using spectrophotometric method according to Chang et al. (39).
Antioxidant activity was determined as $\mathrm{EC}_{50}$ value, i.e. the extract concentration required to obtain $50 \%$ of antioxidant activity based on dose-dependent mode of action.

\section{Theoretical approach}

The following factors were determined to better understand the relationships between biologically active compounds in the light of their potential bioaccessibility: the active compound bioaccessibility index (ACB):

$$
\mathrm{ACB}=w_{\mathrm{DE}} / w_{\mathrm{BE}}
$$

where $w_{\mathrm{DE}}$ is the mass fraction of active compounds in the extract after digestion in vitro $(\mathrm{mg} / \mathrm{g})$, and $w_{\mathrm{BE}}$ is the mass fraction of active compounds in the buffer extract $(\mathrm{mg} / \mathrm{g})$; and the antioxidant bioaccessibility index (BAC), which is an indication of the bioaccessibility of antioxidative compounds:

$$
\mathrm{BAC}=\mathrm{EC}_{50 \mathrm{BE}} / \mathrm{EC}_{50 \mathrm{DE}}
$$

where $\mathrm{EC}_{50 \mathrm{BE}}$ is the value of $\mathrm{EC}_{50}(\mathrm{mg} / \mathrm{mL})$ of buffer extracts, and $\mathrm{EC}_{50 \mathrm{DE}}$ is the value of $\mathrm{EC}_{50}(\mathrm{mg} / \mathrm{mL})$ of extracts after digestion in vitro.

\section{Statistical analysis}

Statistical analysis was done at a significance level of $\alpha=0.05$ using STATISTICA v. 7 (StatSoft, Cracow, Poland). Measurement scores were subjected to analysis of variance (ANOVA). When significant differences in ANOVA were detected, the mean values were compared using the Tukey's test. The Pearson correlation coefficients were also determined.

\section{Results and Discussion}

\section{Physical properties and quality of bread}

Table 1 presents the effect of the addition of various amounts of pumpkin pulp (as converted to dry matter percentage) on the physical and sensory properties of bread. Increase in the mass faction of pumpkin pulp in wheat dough resulted in the production of bread with decreased loaf volume ( $\mathrm{R}=0.991)$ (Fig. 1)

Recent studies have focused on bread supplementation with pumpkin flour obtained after drying and grinding pumpkin flesh. See et al. (14) reported that the specific volume of bread with $5 \%$ pumpkin flour was the highest compared to the other studied levels of pumpkin flour, which gives the bread a more significant softness. On the other hand, the results obtained by El-Demery (15) illustrated that there were no significant differences in loaf volume and loaf mass of toast bread made from $100 \%$ wheat flour and toast bread containing $5 \%$ pumpkin flour. In the same research, the addition of pumpkin flour at a fraction up to $5 \%$ caused a reduction in loaf volume of toast bread; more significant differences were noticed between control treatment and treatments which contained up to $10 \%$ of pumpkin flour.

It was observed that bread with pumpkin pulp had smaller and more compact pores, which caused an increase of the value of the Dallmann index of porosity (Ta- 
Table 1. Basic properties and sensory evaluation of wheat bread with added pumpkin pulp

\begin{tabular}{|c|c|c|c|c|}
\hline \multicolumn{5}{|c|}{ Basic properties } \\
\hline$w($ pulp) & Loaf volume & \multirow{2}{*}{$\begin{array}{c}\text { Bread } \\
\text { pH-value }\end{array}$} & \multirow{2}{*}{\multicolumn{2}{|c|}{$\begin{array}{l}\text { Dallmann porosity } \\
\text { index of crumb }\end{array}$}} \\
\hline$\%$ & $\mathrm{~cm}^{3}$ & & & \\
\hline 0 & $(495.7 \pm 11.5)^{\mathrm{a}}$ & $(5.68 \pm 0.06)^{\mathrm{a}}$ & \multicolumn{2}{|c|}{$(70.0 \pm 7.5)^{\mathrm{a}}$} \\
\hline 5 & $(441.8 \pm 5.8)^{\mathrm{b}}$ & $(5.63 \pm 0.07)^{\mathrm{a}}$ & \multicolumn{2}{|c|}{$(73.3 \pm 5.8)^{\mathrm{a}}$} \\
\hline 10 & $(414.3 \pm 2.3)^{\mathrm{c}}$ & $(5.56 \pm 0.08)^{\mathrm{a}}$ & \multicolumn{2}{|c|}{$(76.7 \pm 5.2)^{\mathrm{ab}}$} \\
\hline 15 & $(350.7 \pm 5.7)^{\mathrm{d}}$ & $(5.50 \pm 0.04)^{\mathrm{b}}$ & \multicolumn{2}{|c|}{$(86.7 \pm 5.3)^{\mathrm{b}}$} \\
\hline 20 & $(326.3 \pm 5.8)^{\mathrm{e}}$ & $(5.49 \pm 0.03)^{\mathrm{b}}$ & \multicolumn{2}{|c|}{$(86.7 \pm 5.5)^{\mathrm{b}}$} \\
\hline \multicolumn{5}{|c|}{ Sensory evaluation } \\
\hline$\frac{w(\text { pulp })}{\%}$ & $\begin{array}{l}\text { Crumb } \\
\text { colour }\end{array}$ & Aroma & Texture & Taste \\
\hline 0 & $(7.4 \pm 0.3)^{a}$ & $(8.6 \pm 0.4)^{a}$ & $(7.7 \pm 0.3)^{\mathrm{a}}$ & $(7.8 \pm 0.2)^{\mathrm{a}}$ \\
\hline 5 & $(7.7 \pm 0.3)^{\mathrm{a}}$ & $(8.4 \pm 0.4)^{a}$ & $(7.7 \pm 0.2)^{\mathrm{a}}$ & $(7.9 \pm 0.5)^{\mathrm{ab}}$ \\
\hline 10 & $(8.4 \pm 0.3)^{\mathrm{b}}$ & $(7.7 \pm 0.3)^{\mathrm{b}}$ & $(7.9 \pm 0.5)^{\mathrm{ab}}$ & $(7.4 \pm 0.2)^{\mathrm{b}}$ \\
\hline 15 & $(8.4 \pm 0.2)^{\mathrm{b}}$ & $(6.6 \pm 0.5)^{\mathrm{c}}$ & $(8.4 \pm 0.2)^{\mathrm{b}}$ & $(6.0 \pm 0.3)^{c}$ \\
\hline 20 & $(8.6 \pm 0.4)^{\mathrm{b}}$ & $(5.6 \pm 0.3)^{\mathrm{d}}$ & $(8.3 \pm 0.2)^{\mathrm{b}}$ & $(4.5 \pm 0.4)^{\mathrm{d}}$ \\
\hline
\end{tabular}

${ }^{*}$ Nine-point hedonic scale of sensory evaluation with 1,5 and 9 representing extremely dislike, neither like nor dislike, and extremely like, respectively. Mean values with different letters in superscript within the same column are significantly different $(\mathrm{p}<0.05)$

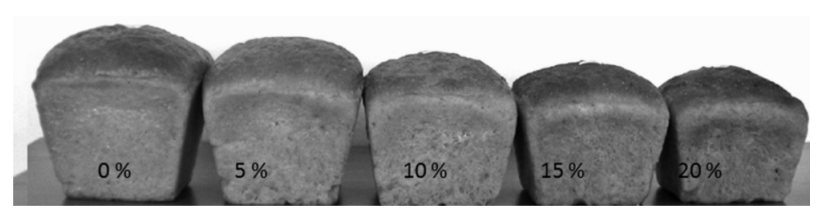

Fig. 1. Overall view of wheat bread with added pumpkin pulp

ble 1). With the increase in the fraction of pumpkin pulp, the $\mathrm{pH}$ value of bread crumb decreased slightly, but significantly $(\mathrm{p}<0.05)$. The $\mathrm{pH}$ of the bread produced from wheat flour was 5.68, while of the bread with $20 \%$ (in percentage of dry matter) pulp it was 5.49 . This $\mathrm{pH}$ value is typical and acceptable. It depends on the type of flour and other raw materials used in the formulation. For example, in the studies presented by Kotancilar et al. (40) bread produced from wheat flour had crumb $\mathrm{pH}=6.0$, while with sourdough addition, it was 4.4.
The results of the sensory evaluation of different types of bread are presented in Table 1. Colour appears to be a very important criterion for initial acceptability of the baked product by the consumers. The enriched bread crumbs were much more orange than the control bread, which had positive influence on bread acceptability. Similar relation was found for sandwich bread enriched with pumpkin flour $(13,15)$. See et al. (14) and El-Demery (15) concluded that the colour of bread crumb was significantly affected by the addition of pumpkin flour. They observed that the redness and yellowness significantly increased but light value decreased with higher percentage of pumpkin flour. The taste, aroma and overall acceptability of control bread and the bread with flour substitution levels of 5 and $10 \%$ had the highest liking score. The addition of higher levels of pumpkin pulp caused an unpleasant aroma and taste. The sensory scores indicated that a partial replacement of wheat flour in bread with up to $10 \%$ pumpkin pulp received satisfactory overall consumer acceptability. In other studies results of sensory investigation of sandwich bread showed that $10 \%$ substitution of wheat flour with pumpkin powder was acceptable by consumers (13). Sensory properties (odour, texture and overall acceptability scores) of toast bread (15) with different levels of wheat flour substitution with pumpkin flour showed that the bread with 5 and $10 \%$ pumpkin flour received the highest scores for all quality attributes.

The addition of pumpkin pulp caused changes in the textural properties of bread crumb (Table 2). With the increase in pumpkin content in dough from 0 to $20 \%$, a linear increase was observed in bread crumb hardness $(R=0.995)$ and chewiness $(R=0.983)$. Results suggest that these texture parameters are also a consequence of reduced bread volume. The addition of pumpkin pulp reduced the elasticity and cohesiveness of bread $(R=0.710$ and 0.665 , respectively).

The crumb of the bread with the added pumpkin pulp was characterized by a lower degree of staling. Moreover, the addition of 10, 15 and $20 \%$ pumpkin improved bread crumb structure homogeneity.

\section{Biological activity of enriched bread}

There is little available research on pumpkin phenolics (vanillic, $p$-coumaric, sinapic, chlorogenic and syringic acids) (41). All of these compounds possess biological activity, thus it can be assumed that pumpkin pulp is a

Table 2. Texture properties of wheat bread crumb with different amount of pumpkin pulp addition

\begin{tabular}{|c|c|c|c|c|c|c|c|}
\hline$\frac{w(\text { pulp })}{\%}$ & $\frac{\text { Hardness }}{\mathrm{N}}$ & $\frac{\text { Elasticity }}{\mathrm{mm}}$ & Cohesiveness & $\frac{\text { Chewiness }}{\mathrm{N} \cdot \mathrm{mm}}$ & $\begin{array}{c}\begin{array}{c}\text { Degree of } \\
\text { staling }\end{array} \\
\%\end{array}$ & $\begin{array}{c}\begin{array}{c}\text { Heterogeneity } \\
\text { index }\end{array} \\
\%\end{array}$ & $\begin{array}{l}\text { Structure } \\
\text { quality }\end{array}$ \\
\hline 0 & $(3.8 \pm 0.3)^{a}$ & $(8.0 \pm 0.2)^{\mathrm{a}}$ & $(0.67 \pm 0.09)^{\mathrm{a}}$ & $(20.7 \pm 4.0)^{\mathrm{a}}$ & $(34.2 \pm 3.6)^{\mathrm{a}}$ & $(35.5 \pm 4.7)^{\mathrm{a}}$ & MHBC \\
\hline 5 & $(5.0 \pm 0.4)^{\mathrm{b}}$ & $(8.1 \pm 0.7)^{\mathrm{a}}$ & $(0.61 \pm 0.02)^{\mathrm{a}}$ & $(24.7 \pm 3.1)^{\mathrm{a}}$ & $(17.7 \pm 4.4)^{\mathrm{b}}$ & $(31.8 \pm 3.0)^{\mathrm{a}}$ & MHBC \\
\hline 10 & $(6.2 \pm 0.3)^{c}$ & $(7.1 \pm 0.2)^{\mathrm{b}}$ & $(0.58 \pm 0.03)^{\mathrm{ab}}$ & $(25.4 \pm 1.7)^{\mathrm{a}}$ & $(25.2 \pm 2.3)^{c}$ & $(20.5 \pm 2.6)^{b}$ & $\mathrm{HBC}$ \\
\hline 15 & $(7.4 \pm 0.6)^{\mathrm{d}}$ & $(7.5 \pm 0.6)^{\mathrm{ab}}$ & $(0.55 \pm 0.03)^{b}$ & $(30.5 \pm 2.7)^{b}$ & $(11.6 \pm 3.2)^{\mathrm{bd}}$ & $(14.6 \pm 1.6)^{c}$ & $\mathrm{HBC}$ \\
\hline 20 & $(8.2 \pm 0.5)^{\mathrm{d}}$ & $(6.8 \pm 0.5)^{\mathrm{b}}$ & $(0.58 \pm 0.08)^{\mathrm{ab}}$ & $(33.0 \pm 7.0)^{\mathrm{b}}$ & $(8.3 \pm 1.3)^{\mathrm{d}}$ & $(13.9 \pm 1.8)^{\mathrm{c}}$ & $\mathrm{HBC}$ \\
\hline
\end{tabular}

Mean values with different superscript letter within the same column are significantly different $(\mathrm{p}<0.05)$

$\mathrm{MHBC}=$ medium homogeneous bread crumb, $\mathrm{HBC}=$ homogeneous bread crumb 
good material for bread complementation with bioactive components.

Taking into account total phenolic content (Table 3), it could be concluded that pumpkin pulp is not a good source of hydrophilic phenolic compounds, including flavonoids; its supplementation did not influence significantly the total phenolic and flavonoid content. Contrary to these results, complementation of wheat bread with pumpkin pulp caused significant increase of buffer-extractable peptide content.

The activity of phenolic compounds studied in vitro (after their isolation from food) does not have to be in accordance with the activity demonstrated in human body. The main factors affecting the bioactivity of polyphenolic compounds include their metabolic transformations and bioavailability (42). Therefore, the biological properties of active compounds may depend on their release from the food matrix during the digestion process (bioaccessibility) and may differ quantitatively from those produced by the chemical extraction employed in most studies (43).

In vitro models based on human physiology have been elaborated as simple, cheap and repeatable tools for the study of food component bioaccessibility. They are widely used for the study of structural changes, digestibility and food component release in simulated conditions of the alimentary tract $(44,45)$. Phenolic compounds from all bread samples were released in digestion in vitro, but their highest content was found in the case of bread with $10 \%$ pumpkin pulp. Similar relationship was found concerning potentially bioaccessible flavonoids. It can be underlined that the content of potentially bioaccessible peptides is correlated with the percentage of the added pulp. Taking into account the active compound bioaccessibility values, it may be concluded that pumpkin pulp is a good source of potentially bioaccessible phenolics (including flavonoids) and, especially peptides, for complementation of bread. The best results were obtained for bread with the addition of 5 and $10 \%$ pumpkin pulp, although higher antioxidant bioaccessibility values were observed of bread containing 15 and $20 \%$ of pulp.

Most literature data confirm the fact that bioactive compounds were released under in vitro conditions; however, data concerning their bioaccessibility are scarce. From the results of the ABTS assay, it can be concluded that the addition of pumpkin pulp significantly enriched the bread with buffer-extractable compounds that have antiradical activity; although a simple relationship was not found. The highest antiradical activity was found in bread with 10 and $15 \%$ of pumpkin pulp. Digestion in vitro released antiradical compounds from all tested bread samples. The highest antiradical activity was observed of samples with 10 and $15 \%$ of pulp, while the addition of $20 \%$ of pulp caused a slight decrease of the tested activity. Antiradical compounds from the pulp were highly bioaccessible in vitro; nevertheless, antioxidant bioaccessibility index (BAC) values may indicate a possibility to form complexes with food matrix components and/or interaction between them. Similar results were obtained in studies concerning bread enriched with ground onion skin; its addition significantly decreased the bioaccessibility of radical scavengers, and the antioxidant activity of the bread was significantly higher than of the control $(27,38)$, which may be partially explained by the formation of flavonoid-protein complexes. These results were confirmed by those obtained by Świeca et al. (46) concerning the bread enriched with quinoa leaf powder. The interactions between quinoa leaf phenolics and bread components (proteins and starch) influenced the antioxidant capacity and nutrient digestibility. The supplementation of bread with the compounds rich in phenolics improves its phenolic content and antioxidant activity; however, the obtained results were different from those expected. The lowering of antioxidant activity may be caused by the blocking of reactive groups of polyphenols by bread components. This idea was supported by the studies of Świeca et al. (47), who showed that the antioxidant potential of bread supplemented with onion skin was lower than expected, which was caused by protein-phenolic interactions. Similarly, interactions between phenolics derived from tea, coffee, cocoa and milk proteins are well known as factors contributing to the reduction of free phenolic contents and the decrease of the antioxidant activity of dairy products (48).

The presented data clearly show that changeable $\mathrm{pH}$ conditions and/or the action of digestive enzymes caused a release of antioxidative compounds able to protect the upper part of the gastrointestinal tract against oxidative damage. Results presented in Table 4 clearly indicate that pumpkin pulp is not a good source of buffer-extractable compounds able to chelate metal ions. In all samples, this activity (CHEL) was significantly lower than in the con-

Table 3. Mass fraction and bioaccessibility of bioactive compounds in bread enriched with pumpkin pulp

\begin{tabular}{|c|c|c|c|c|c|c|c|c|c|}
\hline \multirow{3}{*}{$\frac{w \text { (pulp) }}{\%}$} & \multicolumn{9}{|c|}{$w /(\mathrm{mg} / \mathrm{g})$} \\
\hline & \multicolumn{3}{|c|}{ Total phenolic content } & \multicolumn{3}{|c|}{ Total flavonoid content } & \multicolumn{3}{|c|}{ Total peptide content } \\
\hline & $\mathrm{BE}$ & $\mathrm{DE}$ & $\mathrm{ACB}$ & $\mathrm{BE}$ & $\mathrm{DE}$ & $\mathrm{ACB}$ & $\mathrm{BE}$ & $\mathrm{DE}$ & $\mathrm{ACB}$ \\
\hline 0 & $(6.3 \pm 0.9)^{a}$ & $(19.3 \pm 2.0)^{\mathrm{a}}$ & 3.06 & $(2.8 \pm 0.1)^{\mathrm{a}}$ & $(7.1 \pm 1.0)^{\mathrm{a}}$ & 2.57 & $(1.35 \pm 0.03)^{a}$ & $(16.2 \pm 2.2)^{\mathrm{a}}$ & 12.00 \\
\hline 5 & $(6.1 \pm 0.7)^{\mathrm{a}}$ & $(23.5 \pm 3.2)^{b}$ & 3.88 & $(2.6 \pm 0.2)^{\mathrm{a}}$ & $(10.9 \pm 0.8)^{\mathrm{b}}$ & 4.10 & $(1.85 \pm 0.08)^{\mathrm{b}}$ & $(26.1 \pm 2.3)^{\mathrm{b}}$ & 14.11 \\
\hline 10 & $(7.3 \pm 1.0)^{\mathrm{b}}$ & $(29.7 \pm 3.1)^{c}$ & 4.05 & $(3.9 \pm 0.2)^{\mathrm{b}}$ & $(19.0 \pm 1.2)^{c}$ & 4.90 & $(2.20 \pm 0.05)^{c}$ & $(27.0 \pm 2.2)^{\mathrm{b}}$ & 12.27 \\
\hline 15 & $(6.8 \pm 0.8)^{b}$ & $(27.9 \pm 2.1)^{\mathrm{d}}$ & 2.63 & $(1.91 \pm 0.08)^{c}$ & $(12.6 \pm 0.6)^{d}$ & 6.58 & $(2.60 \pm 0.05)^{c}$ & $(30.6 \pm 2.0)^{c}$ & 11.77 \\
\hline 20 & $(7.2 \pm 0.9)^{\mathrm{b}}$ & $(23.3 \pm 2.0)^{\mathrm{b}}$ & 3.23 & $(1.96 \pm 0.09)^{c}$ & $(11.1 \pm 1.0)^{\mathrm{e}}$ & 5.69 & $(6.20 \pm 0.07)^{\mathrm{d}}$ & $(31.5 \pm 1.9)^{c}$ & 5.08 \\
\hline
\end{tabular}

Mean values with different letter superscript within the same column are significantly different $(\mathrm{p}<0.05)$

$\mathrm{BE}=$ buffer extracts, $\mathrm{DE}=$ extracts after digestion in vitro, $\mathrm{ACB}=$ active compound bioaccessibility index 
Table 4. Biological activities of bread with the addition of pumpkin pulp

\begin{tabular}{|c|c|c|c|c|}
\hline \multirow{2}{*}{$\begin{array}{c}\text { Antioxidant } \\
\text { assay }\end{array}$} & \multirow{2}{*}{$\frac{w(\text { pulp })}{\%}$} & \multicolumn{2}{|c|}{$\mathrm{EC}_{50} /(\mathrm{mg} / \mathrm{mL})$} & \multirow{2}{*}{$\mathrm{BAC}$} \\
\hline & & $\mathrm{BE}$ & $\mathrm{DE}$ & \\
\hline \multirow{5}{*}{ ABTS } & 0 & $(87.0 \pm 0.8)^{\mathrm{a}}$ & $(14.2 \pm 1.1)^{\mathrm{a}}$ & 6.13 \\
\hline & 5 & $(75.7 \pm 2.9)^{\mathrm{b}}$ & $(13.3 \pm 2.1)^{\mathrm{a}}$ & 5.68 \\
\hline & 10 & $(67.6 \pm 2.8)^{c}$ & $(11.9 \pm 0.2)^{\mathrm{b}}$ & 5.66 \\
\hline & 15 & $(68.3 \pm 0.5)^{c}$ & $(12.8 \pm 0.2)^{\mathrm{b}}$ & 5.43 \\
\hline & 20 & $(69.4 \pm 3.1)^{c}$ & $(15.1 \pm 1.1)^{\mathrm{a}}$ & 4.54 \\
\hline \multirow{5}{*}{ CHEL } & 0 & $(38.7 \pm 9.9)^{\mathrm{a}}$ & $(37.7 \pm 6.4)^{\mathrm{a}}$ & 1.03 \\
\hline & 5 & $(59.7 \pm 4.3)^{\mathrm{b}}$ & $(29.1 \pm 3.8)^{\mathrm{b}}$ & 2.06 \\
\hline & 10 & $(78.7 \pm 6.8)^{\mathrm{c}}$ & $(39.1 \pm 0.4)^{c}$ & 2.02 \\
\hline & 15 & $(50.6 \pm 7.0)^{\mathrm{d}}$ & $(49.4 \pm 6.9)^{\mathrm{d}}$ & 1.03 \\
\hline & 20 & $(61.6 \pm 3.5)^{\mathrm{b}}$ & $(55.1 \pm 8.3)^{\mathrm{e}}$ & 1.12 \\
\hline \multirow{5}{*}{ RED } & 0 & $(168.50 \pm 39.06)^{a}$ & $(77.1 \pm 6.1)^{\mathrm{a}}$ & 2.19 \\
\hline & 5 & $(151.5 \pm 12.6)^{b}$ & $(55.0 \pm 5.0)^{\mathrm{b}}$ & 2.75 \\
\hline & 10 & $(82.7 \pm 10.8)^{\mathrm{c}}$ & $(40.6 \pm 1.9)^{\mathrm{c}}$ & 2.04 \\
\hline & 15 & $(116.9 \pm 19.2)^{\mathrm{d}}$ & $(100.2 \pm 15.6)^{\mathrm{d}}$ & 1.17 \\
\hline & 20 & $(160.0 \pm 16.8)^{\mathrm{e}}$ & $(64.1 \pm 3.3)^{\mathrm{e}}$ & 2.50 \\
\hline \multirow{5}{*}{$\mathrm{OH}$} & 0 & $(1.31 \pm 0.06)^{a}$ & $(1.38 \pm 0.03)^{a}$ & 0.95 \\
\hline & 5 & $(1.22 \pm 0.02)^{\mathrm{b}}$ & $(1.5 \pm 0.3)^{b}$ & 0.79 \\
\hline & 10 & $(1.20 \pm 0.07)^{\mathrm{b}}$ & $(1.44 \pm 0.06)^{b}$ & 0.83 \\
\hline & 15 & $(1.25 \pm 0.05)^{\mathrm{b}}$ & $(1.67 \pm 0.05)^{c}$ & 0.75 \\
\hline & 20 & $(1.20 \pm 0.02)^{\mathrm{b}}$ & $(1.5 \pm 0.2)^{\mathrm{a}}$ & 0.81 \\
\hline \multirow{5}{*}{ ACEI } & 0 & $(4761.9 \pm 20.9)^{\mathrm{a}}$ & $(225.4 \pm 13.2)^{\mathrm{a}}$ & 21.13 \\
\hline & 5 & $(3225.8 \pm 19.6)^{b}$ & $(133.1 \pm 8.1)^{b}$ & 24.24 \\
\hline & 10 & $(1923.1 \pm 11.5)^{c}$ & $(92.2 \pm 5.1)^{\mathrm{c}}$ & 20.85 \\
\hline & 15 & $(793.6 \pm 9.2)^{\mathrm{d}}$ & $(54.7 \pm 6.2)^{\mathrm{d}}$ & 14.51 \\
\hline & 20 & $(201.2 \pm 7.2)^{\mathrm{e}}$ & $(20.9 \pm 6.7)^{\mathrm{e}}$ & 9.62 \\
\hline
\end{tabular}

Mean values with different superscript letter within the same column are significantly different $(\mathrm{p}<0.05)$

$\mathrm{BE}=$ buffer extracts, $\mathrm{DE}=$ extracts after digestion in vitro, $\mathrm{ABTS}=$ ability to quench $\mathrm{ABTS}$ radicals, $\mathrm{CHEL}=$ chelating power, $\mathrm{RED}=$ reducing power, $\mathrm{OH}=$ ability to quench $\mathrm{OH}$ radicals, $\mathrm{ACEI}=$ ability to inhibit $\mathrm{ACE}, \mathrm{BAC}=$ antioxidant bioaccessibility index

trol bread. Although digestion in vitro caused the release of active compounds, significantly higher activity was observed only of bread with $5 \%$ pulp. On the other hand, active compounds in bread with 5 and $10 \%$ of pulp were easily bioaccessible in vitro, as indicated by the value of the antioxidant bioaccessibility coefficient. Bread containing pumpkin pulp caused an increase of reducing power in both extracts (buffer and the extract obtained after simulated digestion); however, presented data clearly show that in vitro digestion released reductive compounds. Higher activity was observed of bread with the addition of 5 and $10 \%$ of pulp than of the control sample.

All tested bread loaves were a good source of buffer-extractable components able to neutralize $\mathrm{OH}$ radicals (Table 4). The addition of the pulp did not influence significantly this activity. Surprisingly, digestion in vitro caused slight decrease of the ability to neutralize $\mathrm{OH}$ radicals. Additionally, it seems that the addition of pumpkin pulp influenced slightly negatively the antioxidant activity and potential bioaccessibility of active compounds. These results may infer that bread with pumpkin pulp may be beneficial in the protection of upper gastrointestinal tract from damage caused by free $\mathrm{OH}$ radicals.

It should be emphasized that the control bread has a rather high antioxidant potential; these results may be explained by the fact that bread contains bioaccessible phenolic antioxidants, especially ferulic acid and alkylresorcinols (49). Additionally, thermally processed foods may contain various levels of Maillard reaction products that have been reported to have antioxidant activity (50). These compounds are likely to be bioavailable in vitro and may interact synergistically with pumpkin pulp compounds. The results confirmed the previously observed synergistic interactions between plant bioactive compounds and also food synergy (6).

In general, bread is not a good source of potential mastication-extractable angiotensin-converting enzyme (ACE) inhibitors; however, the addition of pumpkin pulp significantly enriched the bread with these compounds. The highest activity was determined of bread with 15 and 20 $\%$ of the pulp. In vitro digestion caused the release of ACE inhibitors, whose activity was positively correlated with the addition of pumpkin pulp. It is worth noting that $\mathrm{ACE}$ inhibitors from the tested bread were highly bioaccessible in vitro; but the highest antioxidant bioaccessibility values were obtained with bread containing 5 and $10 \%$ pulp (Table 4). The presented results were comparable with the results of bread supplemented with barley flour reported by Alu'datt et al. (51).

High biologically active compound content can be used as the first criterion for the selection of food supplements. However, a compound needs to be bioaccessible and, thus potentially bioavailable. It seems reasonable to assume that pumpkin pulp contains mastication-extractable and potentially bioaccessible compounds, playing an important role in creating biological activity of enriched bread. It must be kept in mind that as a consequence of the extensive modification that occurs in the intestinal and liver cells, the forms reaching the blood and tissues are different from those present in food and thus it is very difficult to identify all the metabolites and evaluate their biological activity (52). The ratio of bioactive compounds plays an important role in the overall activity of their mixtures. Accordingly, the necessity for a holistic approach to the question of the assessment of the biological activity of food supplements is postulated. Statistical analysis showed that ability to neutralize ABTS radicals, reducing power and ACE inhibitory activity of bread were significantly positively correlated with total phenolic compounds, flavonoids and peptide content (Table 5).

Our data support previous reports indicating the superior effects of whole foods over their isolated constituents and demonstrate the relevance of the food synergy concept (53). Contrary to this, no simple relationship is found in the case of chelating power, whereas $\mathrm{OH}$ scavenging ability was negatively correlated with the content of all tested biologically active compounds. Presented data confirmed very complicated interactions between ac- 
Table. 5. Correlation coefficients between the concentration and activity of bioactive compounds

\begin{tabular}{crrr}
\hline & TPC & TFC & PEP \\
\hline ABTS & $\mathbf{0 . 9 4}$ & $\mathbf{0 . 8 0}$ & $\mathbf{0 . 9 4}$ \\
CHEL & 0.10 & 0.12 & 0.01 \\
RED & $\mathbf{0 . 8 6}$ & $\mathbf{0 . 8 3}$ & $\mathbf{0 . 7 3}$ \\
OH & $-\mathbf{0 . 7 5}$ & $-\mathbf{0 . 5 9}$ & $-\mathbf{0 . 9 0}$ \\
ACEI & $\mathbf{0 . 6 5}$ & $\mathbf{0 . 5 0}$ & $\mathbf{0 . 6 9}$ \\
\hline
\end{tabular}

Statistically significant results with $\mathrm{p}<0.05$ are marked in bold. $\mathrm{TPC}=$ total phenolic content, $\mathrm{TFC}=$ total flavonoid content, $\mathrm{PEP}=$ total peptide content, $\mathrm{ABTS}=$ ability to quench $\mathrm{ABTS}$ radicals, $\mathrm{CHEL}=$ chelating power, $\mathrm{RED}=$ reducing power, $\mathrm{OH}=$ ability to quench $\mathrm{OH}$ radicals, $\mathrm{ACEI}=$ ability to inhibit $\mathrm{ACE}$

tive compounds in the whole foods and indicated the need for further research.

The results obtained by Durak et al. (54) concerning interactions between active phytochemicals derived from coffee and cinnamon suggest that the gastrointestinal tract might act as an extractor, whereby antioxidative compounds are progressively released from the food matrix and made bioaccessible, which shows that the food matrix and/or its changes during digestion may play an important role in creating health benefits of functional food.

\section{Conclusions}

In conclusion, pumpkin pulp seems to be a valuable source of active compounds for wheat bread complementation. Adding the pumpkin pulp directly to the wheat flour gives satisfactory baking results and reduces the cost of production. Increase in the pumpkin pulp fraction (in the range from 0 to $20 \%$ ) in wheat dough resulted in the production of bread with decreasing loaf volume and increasing crumb hardness and chewiness. It was observed that bread with pumpkin pulp had smaller and more compact pores. The crumb of the enriched bread was much more orange than that of the control bread, and this had a positive influence on bread acceptability. The quality and sensory characteristics indicated that a partial replacement of wheat flour in bread with up to $10 \%$ (in percentage of dry matter) of pumpkin pulp gave satisfactory results. Higher levels of pumpkin pulp caused an unpleasant aroma and taste. It was shown that the pulp possesses high biological potential, especially angiotensin-converting enzyme inhibitory and antioxidant activities. Additionally, pumpkin pulp is sometimes treated as waste material after seed acquisition, thus using it for bread supplementation also has environmental and economic benefits. Further studies are necessary to address the correlation between the release of biologically active compounds from solid matrices under physiological conditions, their transepithelial passage, chemical modifications and the combined interference with basic cellular properties determining antihypertension and antioxidant activities.

\section{References}

1. M. Carocho, I.C.F.R. Ferreira, A review on antioxidants, prooxidants and related controversy: Natural and synthetic compounds, screening and analysis methodologies and future perspectives, Food Chem. Toxicol. 51 (2013) 15-25. http://dx.doi.org/10.1016/j.fct.2012.09.021

2. Ł. Dobrek, P. Thor, Future potential indications for pharmacotherapy using renin-angiotensin-aldosterone system inhibitory agents, Adv. Clin. Exper. Med. 19 (2010) 389-398.

3. M. Zaman, S. Oparil, D. Calhoun, Drugs targeting the renin-angiotensin-aldosterone system, Nat. Rev. Drug Discov. 1 (2002) 621-636. http://dx.doi.org/10.1038/nrd873

4. L. Das, U. Raychaudhuri, R. Chakraborty, Herbal fortification of bread with fennel seeds, Food Technol. Biotechnol. 51 (2013) 434-440.

5. B. Levaj, V. Dragović-Uzelac, K. Delonga, K. Kovačević Ganić, M. Banović, D. Bursać Kovačević, Polyphenols and volatiles in fruits of two sour cherry cultivars, some berry fruits and their jams, Food Technol. Biotechnol. 48 (2010) 538-547.

6. U. Gawlik-Dziki, Changes in the antioxidant activities of vegetables as a consequence of interactions between active compounds, J. Funct. Food, 4 (2012) 872-882. http://dx.doi.org/10.1016/j.jff.2012.06.004

7. F. Caili, T. Haijun, C. Tongyi, L. Yi, L. Quanhong, Some properties of an acidic protein-bound polysaccharide from the fruit of pumpkin, Food Chem. 100 (2007) 944-947. http://dx.doi.org/10.1016/j.foodchem.2005.10.049

8. D. Leljak-Levanić, H. Čipčić Paljetak, L. Uzelac, S. Mihaljević, N. Bauer, M. Krsnik-Rasol, S. Jelaska, Extracellular glycoproteins in embryogenic culture of pumpkin (Cucurbita pepo L.), Food Technol. Biotechnol. 49 (2011) 156-161.

9. A. Nawirska, A. Figiel, A.Z. Kucharska, A. Sokół-Łętowska, A. Biesiada, Drying kinetics and quality parameters of pumpkin slices dehydrated using different methods, J. Food Eng. 94 (2009) 14-20. http://dx.doi.org/10.1016/j.jfoodeng.2009.02.025

10. Y. Zhang, H. Yao, Study on effect of hypoglycemia of different type pumpkin, J. Chinese Food Sci. 23 (2002) 118-120.

11. N.M. Ptitchkina, L.V. Novokreschonova, G.V. Piskunova, E.R. Morris, Large enhancements in loaf volume and organoleptic acceptability of wheat bread by small additions of pumpkin powder: Possible role of acetylated pectin in stabilising gas-cell structure, Food Hydrocolloid. 12 (1998) 333337.

http://dx.doi.org/10.1016/S0268-005X(98)00024-1

12. S.Y. Giami, H.D. Mepba, D.B. Kiin-Kabari, S.C. Achinewhu, Evaluation of the nutritional quality of breads prepared from wheat-fluted pumpkin (Telfairia occidentalis Hook) seed flour blends, Plant Food Hum. Nutr. 58 (2003) 1-8. http://dx.doi.org/10.1023/B:QUAL.0000041167.61992.4d

13. J. Pongjanta, A. Naulbunrang, S. Kawngdang, T. Manon, T. Thepjaikat, Utilization of pumpkin powder in bakery products, Songklanakarin J. Sci. Technol. 28 (2006) 71-79.

14. E.F. See, W.A. Wan Nadiah, A.A. Noor Aziah, Physico-chemical and sensory evaluation of breads supplemented with pumpkin flour, ASEAN Food J. 14 (2007) 123-130.

15. M.E. El-Demery, Evaluation of physico-chemical properties of toast bread fortified with pumpkin (Cucurbita moschata) flour, The 6th Arab and 3rd International Annual Scientific Conference on Development of Higher Specific Education Programs in Egypt and the Arab World in the Light of Knowledge Era Requirements, Faculty of Specific Education, Mansoura University, Mansoura, Egypt (2011) 13-14. 
16. Cereals and Pulses - Determination of the Nitrogen Content and Calculation of the Crude Protein Content - Kjeldahl Method. ISO Standard 20483:2006, ISO International Organization for Standardization, Geneva, Switzerland (2006).

17. Wheat and Wheat Flour - Gluten Content - Part 1: Determination of Wet Gluten by a Manual Method, ISO Standard 21415-1:2006, ISO International Organization for Standardization, Geneva, Switzerland (2006).

18. Cereals, Pulses and By-Products. Determination of Ash Yield by Incineration, ISO Standard 2171:2007, ISO International Organization for Standardization, Geneva, Switzerland (2007).

19. Wheat, Rye and Their Flours, Durum Wheat and Durum Wheat Semolina - Determination of the Falling Number According to Hagberg-Perten, ISO Standard 3093:2009, ISO International Organization for Standardization, Geneva, Switzerland (2009).

20. Wheat Flour - Physical Characteristics of Doughs - Part 1: Determination of Water Absorption and Rheological Properties Using a Farinograph, ISO Standard 5530-1:1997, ISO International Organization for Standardization, Geneva, Switzerland (1997).

21. T. Jakubczyk, T. Haber: Analysis of Cereals and Cereals Products, Warsaw University of Life Sciences Press, Warsaw, Poland (1983).

22. R. Różyło, Effect of process modifications in two cycles of dough mixing on physical properties of wheat bread baked from weak flour, Food Bioprocess Technol. 7 (2014) 774-783. http://dx.doi.org/10.1007/s11947-013-1100-1

23. M.H. Dallmann: Porosity Tables. In: Progress of Crop Research, Verlag Moritz Schäfer, Detmold, Germany (1981) pp. 4-9 (in German).

24. A. Gámbaro, A. Giménez, G. Ares, V. Gilardi, Influence of enzymes on the texture of brown pan bread, J. Texture Stud. 37 (2006) 300-314.

http://dx.doi.org/10.1111/j.1745-4603.2006.00053.x

25. R. Różyło, Determining the heterogeneity of wheat breadcrumb texture baked using two different methods: New application, Int. J. Food Prop. 16 (2013) 154-167. http://dx.doi.org/10.1080/10942912.2010.535189

26. H.S. Lim, S.H. Park, K. Ghafoor, S.Y. Hwang, J. Park, Quality and antioxidant property of bread containing turmeric (Curcuma longa L.) cultivated in South Korea, Food Chem. 112 (2011) 1577-1582. http://dx.doi.org/10.1016/j.foodchem.2010.08.016

27. Sensory Analysis - Methodology - General Guidance, ISO Standard 6658:2005, ISO International Organization for Standardization, Geneva, Switzerland (2005).

28. Sensory Analysis - Methodology - Ranking, ISO Standard 8587:2006, ISO International Organization for Standardization, Geneva, Switzerland (2006).

29. Sensory Analysis, General Guidance for the Design of Test Rooms, ISO Standard 8589:2007, ISO International Organization for Standardization, Geneva, Switzerland (2007).

30. U. Gawlik-Dziki, M. Świeca, D. Dziki, B. Baraniak, J. Tomiło, J. Czyz, Quality and antioxidant properties of breads enriched with dry onion (Allium cepa L.) skin, Food Chem. 138 (2013) 1621-1628.

http://dx.doi.org/10.1016/j.foodchem.2012.09.151

31. V.L. Singleton, J.A. Rossi, Colorimetry of total phenolics with phosphomolybdic-phosphotungstic acid reagents, Am. J. Enol. Vitic. 16 (1965) 144-158.

32. T. Bahorun, A. Luximon-Ramma, A. Crozier, O.I. Aruoma Total phenol, flavonoid, proanthocyanidin and vitamin C levels and antioxidant activities of Mauritian vegetables, J. Sci. Food Agric. 84 (2004) 1553-1561.

http://dx.doi.org/10.1002/jsfa.1820
33. J. Adler-Nissen, Determination of the degree of hydrolysis of food protein hydrolysates with trinitrobenzenesulfonic acid, J. Agric. Food Chem. 27 (1979) 1256-1262.

http://dx.doi.org/10.1021/jf60226a042

34. R. Re, N. Pellegrini, A. Proteggente, A. Pannala, M. Yang, C. Rice-Evans, Antioxidant activity applying an improved ABTS radical cation decolorization assay, Free Radic. Biol. Med. 6 (1999) 1231-1237. http://dx.doi.org/10.1016/S0891-5849(98)00315-3

35. J.T. Guo, H.L. Lee, S.H. Chiang, H.I. Lin, C.Y. Chang, Antioxidant properties of the extracts from different parts of broccoli in Taiwan, J. Food Drug Anal. 9 (2001) 96-101.

36. M. Oyaizu, Studies on products of browning reaction - Antioxidative activities of products of browning reaction prepared from glucosamine, Jpn. J. Nutr. 4 (1986) 307-315. http://dx.doi.org/10.5264/eiyogakuzashi.44.307

37. X.Y. Su, Z.Y. Wang, J.R. Liu, In vitro antioxidant activity of Pinus korainensis seed extract containing phenolic compounds, Food Chem. 117 (2009) 681-686. http://dx.doi.org/10.1016/j.foodchem.2009.04.076

38. M. Hayakari, Y. Kondo, H. Izumi, A rapid and sample photometric assay of angiotensin-converting enzyme, Anal. Biochem. 84 (1978) 361-369. http://dx.doi.org/10.1016/0003-2697(78)90053-2

39. B. Chang, R. Chen, I. Huang, H. Chang, Assays for angiotensin converting enzyme inhibitory activity, Anal. Biochem. 291 (2001) 84-88. http://dx.doi.org/10.1006/abio.2001.5005

40. H.G. Kotancilar, K.E. Gerçekaslan, M.M. Karaoğlu, Crumb pasting and staling properties of white and traditional Vakfikebir breads, Turk. J. Agric. For. 33 (2009) 435-443.

41. V. Dragovic-Uzelac, K. Delonga, B. Levaj, S. Djakovic, J. Pospisil, Phenolic profiles of raw apricots, pumpkins, and their purees in the evaluation of apricot nectar and jam authenticity, J. Agric. Food Chem. 53 (2005) 4836-4842. http://dx.doi.org/10.1021/jf040494+

42. F. Saura-Calixto, J. Serrano, I. Goni, Intake and bioaccessibility of total polyphenols in a whole diet, Food Chem. 101 (2007) 492-501.

http://dx.doi.org/10.1016/j.foodchem.2006.02.006

43. J. Serrano, I. Goni, F. Saura-Calixto, Food antioxidant capacity determined by chemical methods may underestimate the physiological antioxidant capacity, Food Res. Int. 40 (2007) 15-21.

http://dx.doi.org/10.1016/j.foodres.2006.07.010

44. E.F. Garcia, I.C. Lerida, A.P. Galvez, In vitro bioaccessibility assessment as a prediction tool of nutritional efficiency, Nutr. Res. 29 (2009) 751-760. http://dx.doi.org/10.1016/j.nutres.2009.09.016

45. A.G. Oomen, A. Hack, M. Minekus, E. Zeijdner, C. Cornelis, G. Schoeters et al., Comparison of five in vitro digestion models to study the bioaccessibility of soil contaminants, Environm. Sci. Technol. 36 (2002) 3326-3334. http://dx.doi.org/10.1021/es010204v

46. M. Świeca, Ł. Sęczyk, U. Gawlik-Dziki, D. Dziki, Bread enriched with quinoa leaves - The influence of protein-phenolics interactions on the nutritional and antioxidant quality, Food Chem. 162 (2014) 54-62. http://dx.doi.org/10.1016/j.foodchem.2014.04.044

47. M. Świeca, U. Gawlik-Dziki, D. Dziki, B. Baraniak, J. Czyż, The influence of protein-flavonoid interactions on protein digestibility in vitro and the antioxidant quality of breads enriched with onion skin, Food Chem. 141 (2013) 451-458. http://dx.doi.org/10.1016/j.foodchem.2013.03.048

48. T. Ozdal, E. Capanoglu, F. Altay, A review on protein-phenolic interactions and associated changes, Food Res. Int. 51 
(2013) 954-970.

http://dx.doi.org/10.1016/j.foodres.2013.02.009

49. N.M. Anson, Y.M. Hemery, A. Bast, G.R. Haenen, Optimizing the bioactive potential of wheat bran by processing, Food Funct. 3 (2012) 362-375.

http://dx.doi.org/10.1039/c2fo10241b

50. U. Gawlik-Dziki, D. Dziki, B. Baraniak, R. Lin, The effect of simulated digestion in vitro on bioactivity of wheat bread with Tartary buckwheat flavones addition, LWT-Food Sci. Technol. 42 (2009) 137-143. http://dx.doi.org/10.1016/j.lwt.2008.06.009

51. M.H. Alu'datt, T. Rababah, K. Ereifej, I. Alli, M.A. Alrababah, Effects of barley flour and barley protein isolate on chemical, functional, nutritional and biological properties of pita bread, Food Hydrocolloid. 26 (2012) 135-143.

http://dx.doi.org/10.1016/j.foodhyd.2011.04.018

52. K.B. Pandey, S.I. Rizvi, Plant polyphenols as dietary antioxidants in human health and disease, Oxid. Med. Cel. Longev. 2 (2009) 270-278. http://dx.doi.org/10.4161/oxim.2.5.9498

53. D.R. Jacobs Jr., M.D. Gross, L.C. Tapsell, Food synergy: An operational concept for understanding nutrition, Am. J. Clin. Nutr. (Suppl.), 89 (2009) 1543-1548.

http://dx.doi.org/10.3945/ajcn.2009.26736B

54. A. Durak, U. Gawlik-Dziki, Ł. Pecio, Coffee with cinnamon - Impact of phytochemicals interactions on antioxidant and anti-inflammatory in vitro activity, Food Chem. 162 (2014) $81-88$.

http://dx.doi.org/10.1016/j.foodchem.2014.03.132 